\title{
Seafood consumption patterns among coastal people in Ambon Island, eastern Indonesia
}

\author{
Soselisa, P.S., " Soselisa, H.L. and Alfons, C.R. \\ Fakultas Ilmu Sosial dan Ilmu Politik, Universitas Pattimura, Jl. Ir. M. Putuhena, Kampus Poka, Ambon \\ 97233, Indonesia
}

\begin{abstract}
Article history:
Received: 9 February 2021

Received in revised form: 20

March 2021

Accepted: 23 March 2021

Available Online: 28 July

2021
\end{abstract}

\section{Keywords:}

Seafood,

Fish consumption,

Food patterns,

Coastal communities,

Cultural patterns

DOI:

https://doi.org/10.26656/fr.2017.5(S3).005

\begin{abstract}
Maluku province is the province with the highest level of fish consumption in Indonesia. It exceeds the level of national fish consumption. However, the fish consumption level in Maluku province by the district is uneven. The recent data showed that Ambon City ranks last in the level of fish consumption compared to ten other districts in the province. Whereas local inhabitants who mostly live along the island's coastal areas often claim themselves as "fish-eaters" because of their dependence on seafood, especially fish for daily consumption. This paper illustrated the extent to which claim or identification as "fish-eaters" among the coastal people of Ambon Island can be maintained or proven. Using field data from two villages in the Ambon municipality, the pattern of seafood consumption and distribution were described through household surveys and interviews. The findings showed that the level of seafood consumption was still high for lunch and dinner, which are considered as "heavy meals" compared to breakfast. The source of obtaining seafood was mostly from the community's catch or harvest.
\end{abstract}

\section{Introduction}

Various policies in the form of government regulations, programs, campaigns and appeals are carried out to achieve food security through a food sovereignty strategy. For Indonesia with a total area of $6,400,000$ $\mathrm{km}^{2}$, which has more than 17,000 islands and coastlines over $100,000 \mathrm{~km}$, food sovereignty over seafood is related to access to the sea, the production, distribution and consumption of healthy and nutritious seafood (see Wittman, 2011; HLPE, 2014; Syahyuti et al., 2015; Bennett et al., 2018).

Compared to some countries in Southeast Asia, the Indonesian level of fish consumption is low, $50.69 \mathrm{~kg} /$ capita/year in 2019 (Kementerian Kelautan dan Perikanan, 2020). Of the 8 countries listed in 2015, Indonesia is in the seventh position under Cambodia, the Philippines, Thailand, Myanmar, Laos, and Vietnam (Needham and Funge-Smith 2014). Although it has shown an increasing trend in the last five years, Indonesia's position is still far below that of Malaysia and Singapore until recently (Sekretariat Jenderal Kementerian Kelautan dan Perikanan, 2019; Kementerian Kelautan dan Perikanan (KKP), 2020).

The government of Indonesia has promoted a movement called Gemarikan, which stands for Gerakan
Memasyarakatkan Makan Ikan (movement to promote eating fish) since 2004, a program to stimulate and convince people to consume fish. This was followed by forming Forikan (Forum Peningkatan Konsumsi Ikan), a forum to increase fish consumption in 2006 at the national and regional levels, and establishing November 21 as national fish day, Hari Ikan Nasional (Harkannas) through a presidential decree in 2014. The campaign to eat fish has also been carried out through a 2017 presidential instruction regarding the healthy community movement, Gerakan Masyarakat Sehat, which aims to build individual and collective nutritional awareness in society. These government initiatives are to encourage and to increase demand for fish, to disseminate information about the nutritional content and benefits of eating fish, to increase creativity in processing fish for consumption and culinary business, as well as to change misperceptions and cultural issues about fish in the community.

The level of fish consumption for each province in Indonesia is uneven. The Ministry of Fisheries and Maritime Affairs classifies the level of fish consumption into three categories, namely low, medium and high categories. The fish consumption figure is obtained from the sum of household consumption (Konsumsi Ikan Dalam Rumah Tangga, KIDRT), outside household 
consumption, and unrecorded consumption. According to government data, Maluku is the province with the highest level of fish consumption, $55.13 \mathrm{~kg} / \mathrm{capita} / \mathrm{year}$ (KKP, 2018), exceeding the national figure. Official source obtained from the Maluku fisheries office mentioned a higher figure, $66.67 \mathrm{~kg} /$ capita/year for 2018 .

Given that over $90 \%$ of Maluku is the sea with more than a thousand islands scattered, it is hardly surprising that the people are highly dependent on marine products, particularly for those living on small islands where access to agricultural land is limited. About $85 \%$ of settlements in the province are on the coast and small islands, so that people have great access to food from the sea, either for their own household consumption or as a source of livelihood (Soselisa, 2004; Soselisa, 2007a). Adaptation to the physical environment of islands results in a series of cultural concepts and activities, including the selection of food that is ecologically provided by the environment (Soselisa, 2007b; Ellen and Soselisa, 2012; Soselisa and Ellen, 2013; Hirose, 2014). Maluku people who inhabit small islands and coastal areas feel their diet is incomplete if there is no fish, they even claim to be "fish-eaters".

Available data on fish consumption at the household level (KIDRT) for four years (2015-2018) illustrates variations among eleven districts in Maluku province. It shows that Ambon municipality ranked lowest in 2018 (36.70 kg/capita/year) with a declining trend in four years. These figures raise the question of whether there has been a change in fish consumption patterns among Ambon coastal communities, especially the locals? This study illustrated the current situation of consumption patterns of seafood (fish and other marine resource species) among the Ambonese households and their strategies to obtain it. We selected two villages out of 22 local customary villages (negeri) within the administration area of Ambon City.

\section{Materials and methods}

\subsection{Research location}

This research was undertaken during the east season, between June and August 2019. It was conducted in the villages of Hukurila and Seilale located on the coast of Leitimor Peninsula of Ambon Island (Figure 1). The distance between the village of Hukurila and Ambon as the capital of the Maluku province as well as the capital of the municipality of Ambon is $31.58 \mathrm{~km}$, while the distance from Seilale to Ambon city is closer, $12.29 \mathrm{~km}$. The distance and the available access to Ambon city is one of the reasons for selecting these two villages. The presence of a fish landing base (Pangkalan Pendaratan Ikan, PPI) near Seilale is also an indicator to be examined in relation to sources in obtaining seafood for the locals.

The population of Hukurila and Seilale in 2019 are 689 and 1,622 individuals respectively. Generally, people living in coastal areas in Maluku, including inhabitants of both sample villages engage in agriculture and fishery, as farmers and fishers. Other jobs include car and motorcycle drivers, housebuilders, and kiosk owners

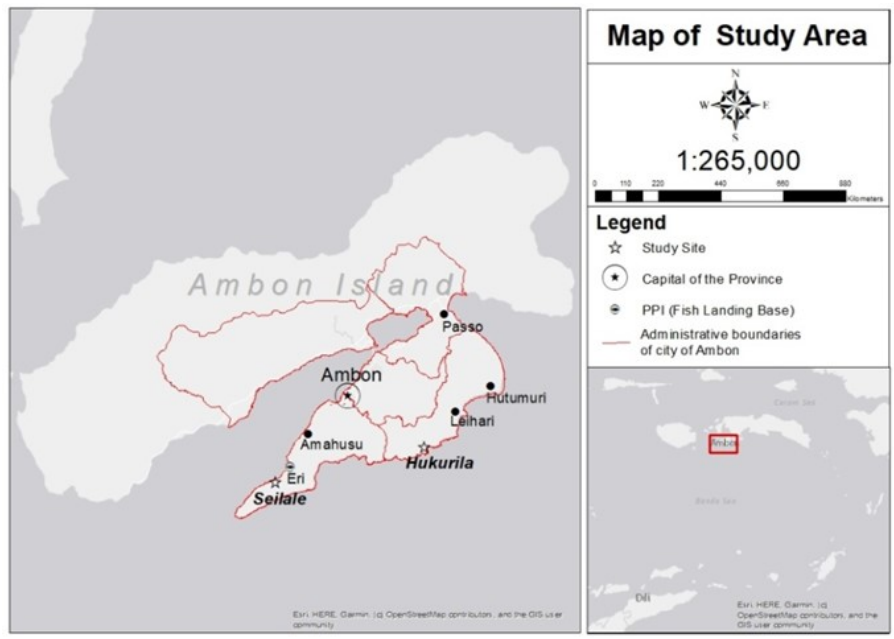

Figure 1. Research site in Ambon Island

\subsection{Data collection}

Household surveys, interviews and observations were used to explore daily meals, methods of obtaining and distributing seafood. The household surveys were carried out in July and August during the east monsoon when both villages experienced rough seas. This is to find out the extent to which the desire to consume food from the sea was maintained, even during the rough season.

In each village, forty households were selected at random, from residential areas near the beach as well as at hilly areas. The livelihood of household heads varies including farmers, fishers, small vendors, housebuilders, drivers and employees. Of the forty households in Hukurila, farmers are the most numerous (35\%), and in Seilale the most are fishers (57.55\%). Although these two villages are located on the coast, their livelihoods are not limited to fishing. In fact, the characteristic of the livelihoods of the coastal local population in Ambon Island is a combination of being farmers and fishers. Some of them carry out these two jobs together or alternate according to the seasons.

Members of 40 households in each village were asked what foods were consumed at three meal times (breakfast, lunch, dinner) per day. They were also asked how they processed the food, whether fried, sautéed, or 
boiled. Household members who were interviewed were those who prepared the food or those who consumed the prepared food. Then, they were asked what methods they used to obtain the food they consume at every meal, especially seafood, whether by fishing, by obtaining from relatives, by purchasing at the market or the fish landing base, as well as by purchasing from the papalele (women who go around the village selling fish) or from stalls in the village. From the three meals survey of 40 households from each village for 28 days (four weeks), 3360 meals were recorded in each village, consisting of 1,120 breakfast, 1,120 lunch, and 1,120 dinners. The total meals listed from 80 households in the two villages were 6720 meals.

Informal interviews were conducted with villagers, males and females, on the topic of the season, fishing activities and marine resources, selling fish, and culinary. Interviews and observations were also undertaken at the central market (pasar Mardika) of Ambon on two women from Hukurila who sold their harvested sea vegetables. We were also involved through participant observation by participating in harvesting sea vegetables with some men, women and children. These marine resources which are harvested annually from June to August contribute to household consumption and production for the market during the rough sea season. Therefore, observation, interviews, and participation in harvesting sea vegetables were significant in this research.

\section{Results and discussion}

\subsection{Pattern of seafood consumption}

The people of Hukurila and Seilale have three meals a day: in the morning (breakfast), afternoon (lunch) and evening (dinner). Table 1 lists the food group consumed at breakfast, lunch and dinner for 28 days from 40 households in each village. The food group is categorized into seafood (i.e. meals that have seafood items: fish and other marine species) and non-seafood.

Table 1 shows that both communities choose fish and other seafood (over 85\%) for their lunch and dinner which they considered as "heavy meals" compared to breakfast. In addition to various species of fish, seafood they consume during this season is sea vegetables (Porphyra marcossi and Grateloupia dictoma), cuttlefish (Sepia spp), and various species of shellfish. In one meal served, it can be found more than one seafood item, for instance, fish and sea vegetables. The number of seafood for lunch $(1,975$ meals or $88.17 \%)$ is higher than for dinner $(1,923$ meals/ $85.85 \%)$ because people generally cook only once a day. If there is not enough food for dinner, then they will cook fast food, such as instant noodles, fried rice, or porridge, or buy yellow rice sold in the village.

For breakfast, people prefer "light meals", such as bread, various cakes, tuber snacks, fried bananas, or fried rice. Fish for breakfast is found in the form of a side dish for yellow rice in Hukurila, and in Seilale fried fish are eaten with rice or sago. The level of seafood consumption in breakfast is very low. Of 1,120 breakfasts in Hukurila, only 37 (3.30\%) contain seafood, and in Seilale only 59 (5.27\%) out of 1,120 . However, Table 1 also shows that of the total 6,720 meals recorded from the two villages, about $60 \%$ of the meals contain seafood, of which Hukurila $(60.36 \%)$ is slightly higher than Seilale (58.51\%). These figures indicate that there is no significant difference between the two coastal villages in their seafood consumption patterns.

The consumption of seafood in Hukurila was recorded more at lunch, namely 1013 meals $(51.29 \%)$, while in Seilale 962 (48.71\%), even though the respondents in Seilale were mostly fishers compared to those in Hukurila. This suggests that differences in livelihoods do not determine seafood consumption patterns among coastal communities on Ambon Island. Thus, Table 1 demonstrates that seafood occupies an important position as the main menu in the dietary habits of local Ambonese people according to their claim as "fish-eaters".

\subsection{Source of obtaining seafood}

Table 2 illustrates the way seafood is obtained for household meals, that is (a) through their own fishing using fishing line, nets, purse seine boat, or through a wading activity called bameti that mostly is done by women in tidal areas; (b) gifts from relatives or

Table 1. Pattern of seafood consumption in Hukurila and Seilale

\begin{tabular}{llcccccc}
\hline \multicolumn{1}{c}{ Mealtime } & Food group & $\begin{array}{c}\text { Hukurila } \\
(\mathrm{n}=3360)\end{array}$ & $\mathrm{P}$ & $\begin{array}{c}\text { Seilale } \\
(\mathrm{n}=3360)\end{array}$ & $\mathrm{P}$ & $\begin{array}{c}\text { Hukurila }+ \\
\text { Seilale }\end{array}$ & $\mathrm{P}$ \\
\hline Breakfast & Seafood & 37 & 3.3 & 59 & 5.27 & 96 & 4.29 \\
$(\mathrm{n}=2240)$ & Non Seafood & 1083 & 96.7 & 1061 & 94.73 & 2144 & 95.71 \\
\hline Lunch & Seafood & 1013 & 90.45 & 962 & 85.89 & 1975 & 88.17 \\
$(\mathrm{n}=2240)$ & Non Seafood & 107 & 9.55 & 158 & 14.11 & 265 & 11.83 \\
\hline Dinner & Seafood & 978 & 87.32 & 945 & 84.38 & 1923 & 85.85 \\
$(\mathrm{n}=2240)$ & Non Seafood & 142 & 12.68 & 175 & 15.62 & 317 & 14.15 \\
\hline
\end{tabular}


Table 2. Source of obtaining seafood

\begin{tabular}{|c|c|c|c|c|c|c|}
\hline \multirow[b]{2}{*}{ Source of obtaining seafood } & \multicolumn{2}{|c|}{ Breakfast } & \multicolumn{2}{|c|}{ Lunch } & \multicolumn{2}{|c|}{ Dinner } \\
\hline & $\begin{array}{l}\text { Hukurila } \\
(\mathrm{n}=37)\end{array}$ & $\begin{array}{l}\text { Seilale } \\
(\mathrm{n}=59)\end{array}$ & $\begin{array}{l}\text { Hukurila } \\
(\mathrm{n}=1013)\end{array}$ & $\begin{array}{c}\text { Seilale } \\
(\mathrm{n}=962)\end{array}$ & $\begin{array}{l}\text { Hukurila } \\
(\mathrm{n}=978)\end{array}$ & $\begin{array}{c}\text { Seilale } \\
(\mathrm{n}=945)\end{array}$ \\
\hline Fishing & 6 & 39 & 578 & 591 & 562 & 562 \\
\hline$(\mathrm{n}=2,338)$ & $16.21 \%$ & $66.10 \%$ & $57.06 \%$ & $61.44 \%$ & $57.47 \%$ & $59.47 \%$ \\
\hline From relatives/neighbors & - & 4 & 121 & 191 & 102 & 173 \\
\hline$(\mathrm{n}=591)$ & & $6.77 \%$ & $11.94 \%$ & $19.85 \%$ & $10.43 \%$ & $18.30 \%$ \\
\hline Buy from papalele fish seller & - & 6 & 143 & 143 & 127 & 117 \\
\hline$(n=536)$ & & $10.17 \%$ & $14.12 \%$ & $14.86 \%$ & $12.98 \%$ & $12.39 \%$ \\
\hline Buy at the marketplace in Ambon city & - & - & 171 & 15 & 152 & 14 \\
\hline$(n=352)$ & & & $16.88 \%$ & $1.56 \%$ & $15.54 \%$ & $1.48 \%$ \\
\hline Buy at fish landing base & - & 5 & - & 13 & - & 20 \\
\hline$(\mathrm{n}=38)$ & & $8.48 \%$ & & $1.35 \%$ & & $2.12 \%$ \\
\hline Buy cooked food & 31 & 5 & - & 9 & 35 & 59 \\
\hline$(\mathrm{n}=139)$ & 83.79 & $8.48 \%$ & & $0.94 \%$ & $3.58 \%$ & $6.24 \%$ \\
\hline
\end{tabular}

neighbours returning from fishing, usually, fish are given on the beach when they arrive with the catch; (c) by buying from papalele women who sell fish caught by their husbands or other fishermen; (d) by buying at the central market in Ambon city; (e) by buying at the fish landing base (PPI) in Eri, the village next to Seilale; and (f) by buying cooked food with fish as a side dish, mostly from the sellers in the village.

Table 2 shows that most of the seafood for breakfast in Seilale and lunch and dinner in the two communities were obtained from the sea by own fishing (above 57\%). It also occurred in Hukurila where farmers' households were the largest sample taken. Source of seafood through their own fishing numbered 2,338 (58.54\%) for the two sample villages. If we combine it with the gifts from relatives or neighbours who come also from the givers' own catch, then the amount is 2,929 (73.34\%), far above the purchased seafood (purchase at the papalele, at the market, at the PPI).

Available access to Ambon city did not significantly affect the source of obtaining seafood from the central market (only $8.8 \%$ ) even though during the rough season when some of them find it difficult to go fishing. However, from 352 seafood meals obtained from purchases at the city market, the number in Hukurila was higher, both for lunch (48.58\%) and for dinner (43.18\%) compared to Seilale which was only $4.26 \%$ for lunch and $3.98 \%$ for dinner, even though Seilale is closer to Ambon city centre than Hukurila. This data is in line with the role of Seilale (and its neighbouring village, Latuhalat) in supplying fish to markets in Ambon city, particularly the pelagic catch from the operation of the purse-seine units. The number of purse-seine units in Seilale is much less than in Latuhalat, however, some of the Seilale fishermen work on Latuhalat purse seine boats as crews (masnait). In addition, during the rough season, the Latuhalat purse seine boats take shelter on the part of Seilale beach which is protected from the waves. Pelagic species, especially small pelagic are very important for the availability of fish in Ambon for local consumption. Crew members usually bring home their share from the catch (ikan makan, "fish to eat").

The presence of PPI had a little direct impact on the provision for household fish consumption of Seilale people, only 38 meals $(1.9 \%)$ out of 1,966 seafood meals recorded in the village of Seilale. Cooked food with fish as a side dish was purchased mostly for dinner (94 meals out of 139) when there was no leftover from lunch.

Source of seafood through fishing by themselves proves that local communities living near the sea for generations have fishing skills and prefer to fulfil their own desire for seafood by their own fishing, particularly during the rough season when fish prices rise. They often engage in a double occupation, as both farmers and fishers. This indicates a coping strategy for island communities in response to seasonal changes and as a means of managing the environment. The fish supply from the local sea for household consumption through kinship and neighbour ties (591 meals) also confirms the cultural function of marine resources as food in managing resource availability related to seasonal changes, local food security, and social relationship between people in Hukurila as well as Seilale.

The contribution of women is significant through wading activities (bameti) to harvest non-fish marine resources, especially harvesting several seasonal sea vegetable species (sayur isi and sayur karang) in the tidal areas during the east season in Hukurila (Figure 2). In addition to household consumption, Hukurila women sell sea vegetables at the Ambon city market. Usually, they return home with fish they bought at the market for 
their own consumption because of the lack of local fish production during the rough season. Table 2 shows the tendency to buy fish at the Ambon market is higher in Hukurila than in Seilale.

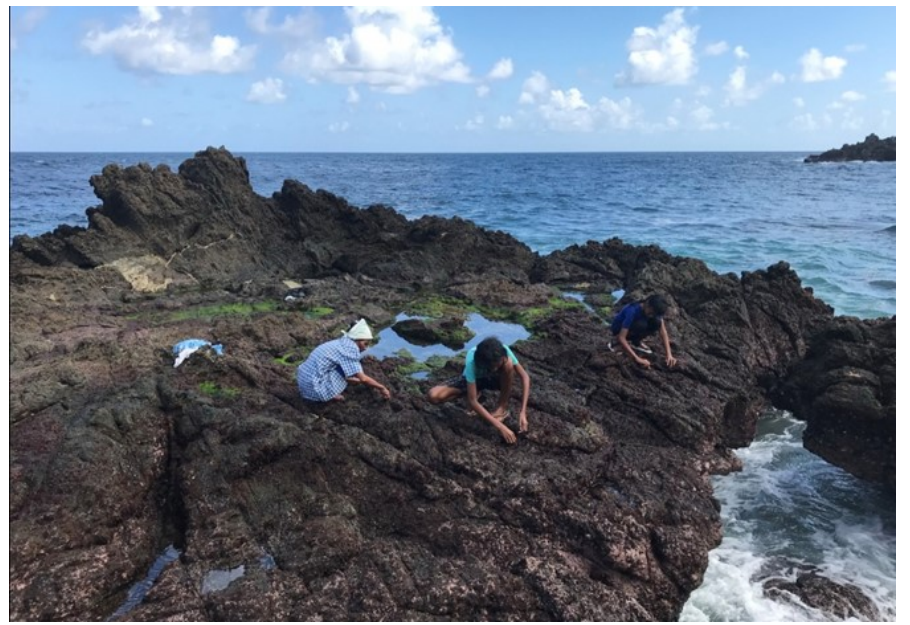

Figure 2. Women and children harvesting sea vegetables.

Local women also play an important role in the distribution of fish for household consumption through their role as fish sellers (papalele) who walk around the village selling fish. 536 seafood meals (13.4\%) were obtained from papalele (Table 2). The papalele women sell fish caught by fishermen in the village or outside the village. When fish are lacking on the coast facing the east season, the papalele will search for fish that come from western fishing grounds.

Coastal and small island communities need to be maintained as consumers and producers as well as distributors of marine resources (seafood) in order to control their food system to achieve food security through a food sovereignty strategy (Wittman, 2011). This is closely associated with their local ecological knowledge of marine resources and areas, which results in fishing activities and techniques. Furthermore, food sovereignty over seafood is arranged through the practices of a number of bundles of sea rights and relations (Schlager and Ostrom, 1992; von BendaBeckmann and Taale, 1996; von Benda-Beckmann and von Benda-Beckmann, 2001) as well as the ability to benefit from local marine resources in the context of bundles and webs of powers that configure resource access of local actors (Ribot and Peluso, 2003).

\section{Conclusion}

Seafood and fish is still an important part of daily consumption among local communities in Ambon Island, even during rough seasons. The relationship with the marine environment that is inseparable from the terrestrial environment makes small-island communities appear as both producers and consumers of marine resources. The meaning of marine resources they consume goes beyond 'a food'; it contains distinctive cultural values that serve to maintain the social environment as well.

\section{Acknowledgement}

The research project was funded by Pattimura University in 2019. We would like to thank our informants and respondents in the village of Hukurila and Seilale for their support, cooperation and hospitality. Special thanks to Lainord Hahijary, Deland Tehupuring, and Dynand Xerxes JS for their assistance with the research.

\section{References}

Bennett, A., Patil, P., Kleisner, K., Rader, D., Virdin, J. and Basurto, X. (2018). Contribution of Fisheries to Food and Nutrition Security: Current Knowledge, Policy, and Research. NI Report 18-02. Durham, NC: Duke University. Retrieved on July 17, 2020 from: https://nicholasinstitute.duke.edu/sites/default/ files/publications/

contribution_of_fisheries_to_food_and_nutrition_se curity_0.pdf

Ellen, R. and Soselisa, H.L. (2012). A comparative study of the socio-ecological concomitants of cassava (Manihot esculenta Crantz): diversity, local knowledge and management in eastern Indonesia. Ethnobotany Research and Applications, 10, 15-35. https://doi.org/10.17348/era.10.0.015-035

Hirose, T. (2014). Survival strategies of a society dependent on Borassus flabellifer during the dry season in Raijua Island, eastern Indonesia: analysis of diet, livelihood, and society. People and Culture in Oceania, 30, 57-72.

HLPE. (2014). Sustainable fisheries and aquaculture for food security and nutrition. A Report by the High Level Panel of Experts on Food Security and Nutrition of the Committee on World Food Security, Rome. Retrieved on July 17, 2020 from http:// www.fao.org/3/a-i3844e.pdf

Kementerian Kelautan dan Perikanan (KKP). (2020). Laporan Kinerja Kementerian Kelautan dan Perikanan Tahun 2019. Jakarta, Indonesia: Kementerian Kelautan dan Perikanan. [In Bahasa Indonesia].

Needham, S. and Funge-Smith, S.J. (2014). The Consumption of Fish Products in the Asia-Pacific Region based on Household Surveys. Bangkok: FAO Regional Office for Asia and the Pacific, Bangkok, Thailand. RAP Publication 2015/2. Retrieved on November 15, 2020 from: http://www.fao.org/3/ai5151e.pdf 
Ribot, J.C. and Peluso, N.L. (2003). A theory of access.

Rural Sociology, 68(2), 53-181. https:// doi.org/10.1111/j.1549-0831.2003.tb00133.x

Schlager, E. and Ostrom, E. (1992). Property rights regimes and natural resources: a conceptual analysis. Land Economics, 68(3), 249-262. https:// doi.org/10.2307/3146375

Sekretariat Jenderal Kementerian Kelautan dan Perikanan (KKP). (2019). Laporan Tahunan 2018. Jakarta, Indonesia: Kementerian Kelautan dan Perikanan. [In Bahasa Indonesia].

Soselisa, H.L. (2004). Fishers of Garogos: Livelihood and Resource Management in a Maluku Island. Darwin, Australia: Charles Darwin University Press.

Soselisa, H.L. (2007a). Antara Tanah dan Air: Tradisi Laut Masyarakat Pulau-Pulau Kecil di Kepulauan Aru Maluku. Yogyakarta, Indonesia: PT. Citra Aji Parama. [In Bahasa Indonesia].

Soselisa, H.L. (2007b). A comparison of traditional and innovative subsistence strategies on Buano during periods of socio-environmental stress, 1980-2003. In Ellen, R. (Ed). Modern Crises and Traditional Strategies Local Knowledge in Island Southeast Asia, p. 143-165. New York, USA: Berghahn Books.

Soselisa, H.L. and Ellen, R. (2013). The management of cassava toxicity and its changing sociocultural context in the Kei Islands, eastern Indonesia. Ecology of Food and Nutrition, 52(5), 427-450. https://doi.org/10.1080/03670244.2012.751913

Syahyuti, Sunarsih, Sri Wahyuni, Sejati, W.K. and Azis, M. (2015). Kedaulatan pangan sebagai basis untuk mewujudkan ketahanan pangan nasional. Forum Penelitian Agro Ekonomi, 33(2), 95-109. https:// doi.org/10.21082/fae.v33n2.2015.95-109

von Benda-Beckmann, F. and Taale, T. (1996). Land, trees and houses: changing (un)certainties in property relationships on Ambon. In Mearns, D. and Healey, C. (Eds). Remaking Maluku, Sosial Transformation in Eastern Indonesia, p. 39-63. Darwin, Australia: Northern Territory University.

von Benda-Beckmann, F. and von Benda-Beckmann, K. (2001). Jaminan Sosial, Sumber Daya Alam dan Kompleksitas Hukum. In von Benda-Beckmann, F., von Benda-Beckmann, K., and Koning, J. (Eds). Sumber Daya Alam dan Jaminan Sosial, p. 23-60. Yogyakarta, Indonesia: Pustaka Pelajar. [In Bahasa Indonesia].

Wittman, H. (2011). Food sovereignty a new rights framework for food and nature. Environment and Society, 2, 87-105. 